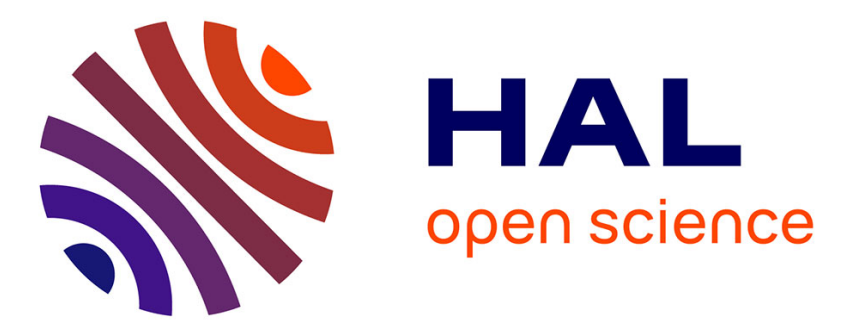

\title{
Plasma and hepatic lipids and lipoproteins in the underfed high-yielding dairy cow during early lactation
}

Denys Durand, M Martinaud, Dominique Gruffat, L Leplaix-Charlat, J Lefaivre, A Ollier, Jc Robert, Y Chilliard, Dominique Bauchart

\section{- To cite this version:}

Denys Durand, M Martinaud, Dominique Gruffat, L Leplaix-Charlat, J Lefaivre, et al.. Plasma and hepatic lipids and lipoproteins in the underfed high-yielding dairy cow during early lactation. Annales de zootechnie, 1994, 43 (Suppl1), pp.46s-47s. hal-00889127

\section{HAL Id: hal-00889127 \\ https://hal.science/hal-00889127}

Submitted on 1 Jan 1994

HAL is a multi-disciplinary open access archive for the deposit and dissemination of scientific research documents, whether they are published or not. The documents may come from teaching and research institutions in France or abroad, or from public or private research centers.
L'archive ouverte pluridisciplinaire HAL, est destinée au dépôt et à la diffusion de documents scientifiques de niveau recherche, publiés ou non, émanant des établissements d'enseignement et de recherche français ou étrangers, des laboratoires publics ou privés. 
Body lipid mobilization, acetonemia and hepatic steatosis in the underfed highyielding dairy cow during early lactation. Y Chilliard 1, A Ollier 1, D Durand 2, R Lefaivre 1, M Tourret 1, D Thomas 1, E Girard 1, G Sauvage 1, D Gruffat 2, JC Robert ${ }^{3}, \mathrm{P}$ Williams ${ }^{3}, \mathrm{D}$ Bauchart ${ }^{2}\left({ }^{1}\right.$ INRA, Laboratoire Sous-Nutrition des Ruminants, 2 INRA, Laboratoire Croissance et Métabolismes des Herbivores, 63122 Saint-GenèsChampanelle, ${ }^{3}$ Rhône Poulenc Nutrition Animale, 03600 Commentry, France)

Relationships between lipid mobilization, ketonemia and hepatic steatosis were studied in 15 highproducing Holstein cows. Animals were fattened before calving (body condition score, BCS, of $3.9 \pm 0.5)$ and received post-partum a low-concentrate $(<25 \%)$ corn silage complete diet ad libitum. Rump subcutaneous adipose tissue and liver samples were taken by biopsy and blood samples obtained before morning feeding, on $\mathrm{d} 4$, 11,25 and $80(71-89)$ of lactation.

During weeks 2-6 of lactation, milk yield was $34.4 \pm 3.3 \mathrm{~kg} / \mathrm{d}$ and net energy balance was $-13.3 \pm 2.5 \mathrm{Mcal} / \mathrm{d}$. Peak milk yield occurred between weeks 4 and 9 . The losses of estimated body mass were 74 and $32 \mathrm{~kg}$ between weeks 1-4 and 4-12, respectively. The corresponding losses of BCS were 0.84 and 0.75 , whereas decreases in adipocyte mean volume were 154 and $261 \mathrm{pl}$. On d 4, 11, 25 and 80 the piasma metabolite values were respectively: $1.4,1.3,1.1$ and $0.4 \mathrm{mM}$ for non-esterified fatty acids (NEFA); $86,73,64$ and $58 \mu \mathrm{M}$ for free glycerol; $1.1,2.4,3.0$ and $0.5 \mathrm{mM}$ for 3 -hydroxybutyrate (3HB); 1.1 , $4.3,5.0$ and $0.2 \mathrm{mg} / \mathrm{dl}$ for acetone; $0.9,1.1,1.6$ and $0.8 \mathrm{mM}$ for acetate; $47,41,41$ and $59 \mathrm{mg} / \mathrm{dl}$ for glucose; and $6.2,6.1,7.0$ and $9.7 \mu \mathrm{U} / \mathrm{ml}$ for insulin. The percentages of C18:1 in milk fat were $32.4,35.5,34.9$ and 25.7 , and values of liver lipids were 78, 131, 104 and $34 \mathrm{mg} / \mathrm{g}$.

For all cows at all lactation stages $(n=59)$, liver lipids were correlated to NEFA, 3HB, acetone, milk fat content, milk $\mathrm{C} 18: 1$, glycemia and energy balance $(r=0.55,0.72,0.73,0.68,0.67$, -0.80 and -0.69 , respectively), whereas plasma $3 \mathrm{HB}$ was correlated to acetone, acetate, milk C18:1 and glycemia ( $r=0.94,0.80,0.64$ and -0.80 , respectively).

These results show that maximal lipid infiltration in the liver occurs rapidly following post-par- tum body lipid mobilization, whereas maximal ketone body and acetate production by the liver is more closely correlated with hypoglycemia occurring at peak milk (lactose) yield.

Plasma and hepatic lipids and lipoproteins in the underfed high-yielding dairy cow during early lactation. D Durand 1, M Martinaud 1, D Gruffat 1, L Leplaix-Charlat ${ }^{1}, \mathrm{~J}$ Lefaivre ${ }^{1}, \mathrm{~A}$ Ollier ${ }^{2}$, JC Robert ${ }^{3}$, $Y$ Chilliard ${ }^{2}$, D Bauchart ${ }^{1}\left({ }^{1}\right.$ INRA-CHM, 2 INRA-SNUT, 63122 Saint-Genès-Champanelle, 3 RPNA, 03600 Commentry, France)

In high-yielding dairy cows, intense fat mobilization during early lactation results in severe infiltration of the liver with lipid. Relationships between fatty liver and plasma energy metabolites, apolipoproteins B (apo B) and A-I (apo A-I) and low (LDL) and high (HDL) density lipoproteins have been studied. Further light may be shed on these relationships from data collected in kinetic studies on the same animals and from knowledge of the complete resolution of LDL and HDL occurring in the bovine in the same density range.

Fifteen Hostein cows were overfed during gestation and underfed after parturition to increase fat mobilization and precipitate hepatic steatosis. Samples of blood $(80 \mathrm{ml})$ and liver $(200 \mathrm{mg})$ were simultaneously obtained from each cow at 1, 2, 4 and 12 weeks after calving. Plasma lipids (nonesterified fatty acids (NEFA) and triacylglycerols (TG)), total cholesterol (C), and hepatic lipids (TG, $\mathrm{C}$ and phospholipids (PL)), were determined by enzymatic or colorimetric methods. Plasma apo $B$ and $A-I$ were measured by radial immunodiffusion. Plasma LDL and HDL were isolated by gradient density ultracentrifugation and purified by heparin-Sepharose affinity chromatography.

During weeks 1, 2, 4 and 12 post-calving, hepatic TG were $85,199,158$ and $10 \mathrm{~g} / 10^{9}$ cells, respectively (representing 75 and $14 \%$ of total hepatic lipids in weeks 2 and 12, respectively). Over the same period, hepatic $C$ and $P L$ were constant but both plasma LDL and very light $\mathrm{HDL}$ increased markedly ( 18 to 61 and 5 to $83 \mathrm{mg} / \mathrm{dl}$, respectively). Cows with lowest hepatic TG levels in week 1 (42 mg/109 cells) developed maximal TG infiltration in week $4\left(178 \mathrm{mg} / 10^{9}\right.$ cells) whereas cows with moderate or severe steatosis in week 1 (80 and $134 \mathrm{mg} / 10^{9}$ cells) developed 
maximal steatosis as early as week 2 (168 and $292 \mathrm{mg} / 10^{9}$ cells, respectively). Our results showed that NEFA is the best plasma predictor for TG liver infiltration in weeks $1(r=0.68), 2(r=0.42)$ and $4(r=0.57)$. Furthermore, plasma LDL, apo $B$ and $A-I$ are other potential predictors with the accuracy of prediction dependent on the time post-partum.

Insulin uptake and effect on glucose utilization by ovine and bovine adipose tissue cultured over 7 days. $Y$ Faulconnier, L Guillon, R Lefaivre, M Tourret, Y Chilliard (INRA, Laboratoire Sous-Nutrition des Ruminants, 63122 Saint-Genès-Champanelle, France)

The effect of insulin $(2 \mathrm{mU} / \mathrm{ml})$ on glucose utilization was studied on adipose tissue (AT) explants from non-lactating non-pregnant cows $(n=5)$ and ewes $(n=5)$ fed a restricted diet $(20-22 \%$ of energy maintenance requirement, EMR) for $8-10 d$ and then overfed (188 or $228 \%$ of EMR, for cows or ewes) during 21 (cows) or 10 (ewes) d until slaughter, to induce a rebound in lipogenic activities. The body condition (scale $0-5$ ) of the cows and ewes averaged $2.5 \pm 0.6$ and $3.0 \pm 0.3$, and the mean adipocyte diameter $122 \pm 3$ and $111 \pm 9 \mu \mathrm{m}$, respectively.

Samples of perirenal AT were cut into 10-15 $\mathrm{mg}$ pieces, and cultured over $7 \mathrm{~d}$ in sterile conditions in medium 199 supplemented with acetate $(7.0 \mathrm{mM})$. The culture medium was changed daily. Glucose concentration was measured using the glucose dehydrogenase method. The loss of insulin from the cultured medium in the 2 species ranged from 60 (1st $d$ of culture) to approximately $35 \%$ ( 2 to $d 7$ ) of the initial amount.

In basal conditions, the glucose utilization was similar (33-24 and $16 \mu \mathrm{mol} / 24 \mathrm{~h} / 10^{6}$ adipocytes on $d 1-2,3-4$ and $5-6-7$, respectively) in the 2 species. However, the glucose utilization by bovine AT was higher $(+18 \%)$ during the 2 nd than during the 1 st $d$, in contrast to ovine AT where this utilization decreased $(-13 \%)$ during this period. In the 2 species, the glucose utilization then progressively decreased until $\mathrm{d} 7$.

The addition of insulin increased $(P<0.001)$ glucose utilization in the 2 species. However, the effect of insulin was different according to the species and the day of culture (interaction species $x$ insulin $x$ day, $P<0.03$ ). The effect of insulin on d 1 was greater in bovine $(+67 \%)$ than in ovine (+20\%) AT, whereas on d 3-4 and d 5-6-7 this effect was greater in ovine (+92 and $132 \%$ ) than in bovine (+64 and $50 \%)$ AT.

This study indicates that ruminant AT explants remain metabolically active for at least $7 d$ when maintained in a suitable medium, with interactions between insulin and animal species that affect glucose utilization.

\section{Hepatic apo B and mRNA apo B levels in the underfed high-producing dairy cow during early lactation. D Gruffat 1 , F} Duboisset 1, D Durand 1, J Lefaivre 1, A Ollier $^{2}$, G d'Onofrio ${ }^{3}$, P Williams ${ }^{4}$, Y Chilliard ${ }^{2}$, D Bauchart 1 ( 1 INRA, Laboratoire Croissance et Métabolismes des Herbivores; 2 INRA, Laboratoire Sous-Nutrition des Ruminants, 63122 Saint-Genès-Champanelle; 3 INSERM U 321, Hôpital de la Pitié, 75013 Paris; ${ }^{4}$ Rhône Poulenc Nutrition Animale, 03600 Commentry, France)

In high-producing dairy cows in early lactation, intense mobilization of lipids is often associated with fatty liver syndrome. The limited capacity of the liver to export triglyceride-rich lipoproteins in the form of very low density lipoproteins (VLDL) increases the risk of development of fatty liver. In cows in early lactation, synthesis of apolipoprotein B (apo B), the major apolipoprotein in VLDL, may be a rate-limiting step for hepatic VLDL production and secretion.

Eight multiparous $\mathrm{H} \times \mathrm{F}$ fat cows after calving (body condition score: $3.9 / 5)$ were offered a low concentrate $(<25 \%$ DM diet) - corn silage complete diet to increase fat mobilization and to induce hepatic steatosis. All cows were liver biopsied $(400 \mathrm{mg} / \mathrm{cow}$; samples frozen in liquid nitrogen) at 1,2, 4, and 12 weeks after calving. Total hepatic RNA was extracted from each biopsy sample using guanidium thiocyanate/phenol/chloroform. Levels of mRNA for apo B were determined by the Dot-blot method using a cDNA human probe and hepatic apo $B$ levels were measured by Western-blot using rabbit specific antibody against bovine apo $B$. Hepatic DNA was determined by fluorimetric method and was used to express the apo $B$ levels per $10^{9}$ hepatic cells.

Levels of mRNA of apo $B$ remained stable after calving $(8.4 \pm 1.0,8.3 \pm 1.8,10.6 \pm 1.3$, and 